\title{
Penerapan Model Pembelajaran Berbasis Riset Berintegrasi Pendidikan Karakter Bagi Guru SMA/SMK Se-Kota Gorontalo
}

\author{
Nova Elysia Ntobuo ${ }^{1}$, Asri Arbie ${ }^{2}$, Lanto M. Kamil Amali ${ }^{3}$ \\ 1,2Pendidikan Fisika Universitas Negeri Gorontalo \\ ${ }^{3}$ Teknik Elektro Universitas Negeri Gorontalo \\ Email: novantobuo81@gmail.com¹; asriarbie@ung.ac.id ${ }^{2}$; \\ kamilamali77@gmail.com ${ }^{3}$
}

\begin{abstract}
ABSTRAK
Kegiatan ini bertujuan untuk memberikan bekal keilmuwan dan keterampilan bagi guru Fisika SMA/SMK tentang penerapan model pembelajaran berbasis riset berintegrasi pendidikan karakter. Target dalam pelaksanaan kegiatan ini adalah meningkatnya keilmuwan dan keterampilan peserta pelatihan, sehingga akan berdampak positif pada peningkatan keterampilan, karakter dan hasil belajar siswa. Selain itu, melalui kegiatan ini ditargetkan disusunnya perangkat pembelajaran sains oleh guru-guru peserta pelatihan dengan menerapkan model pembelajaran berbasis riset berintegrasi pendidikan karakter dalam pembelajaran Fisika di SMA/SMK. Metode yang dipilih yaitu dengan melaksanakan kegiatan pelatihan penerapan model pembelajaran berbasis riset berintegrasi pendidikan karakter bagi guru SMA/SMK di Kota Gorontalo. Kegiatan pelatihan ini akan dimulai dengan pemberian materi tentang model-model pembelajaram berbasis riset, pendidikan berkarakter, sosialisasi perangkat pembelajaran hasil penelitian dan simulasi dari penerapan perangkat pembelajaran hasil penelitian. Selanjutnya, kegiatan berikut adalah pembimbingan penyusunan perangkat pembelajaran dan simulasi atas perangkat yang telah disusun tersebut. Kegiatan pengabdian ini diakhiri dengan pelaksanaan evaluasi dalam bentuk praktek langsung di sekolah masing-masing yang akan diamati langsung oleh tim pelaksana IbM dan pengawas sekolah. Hasil yang dicapai pada pelaksanaan kegiatan IbM ini adalah Guru Fisika SMA/SMK dapat merancang dan menyusun perangkat pembelajaran melalui penerapan model pembelajaran berbasis riset berintegrasi pendidikan karakter dan dapat menerapkannya dalam proses pembelajaran, dihasilkannya 20 buah Perangkat pembelajaran (meliputi RPP, Buku Ajar, LKPD, Tes Hasil Belajar, instrumen aktivitas peserta didik berbasis riset dan Instrumen penilaian karakter peserta didik) yang disusun oleh peserta kegiatan pelatihan.
\end{abstract}

Kata Kunci: Model Pembelajaran berbasis riset, Fisika, SMA/SMK, Pendidikan Karakter

\section{ABSTRACT}

This activity aims to provide scholarly and skills for high school / vocational physics teachers on the application of research-based learning model integrated character education. The target in the implementation of this activity is increasing the knowledge and skills of the trainees, so that will have a positive impact on improving the skills, character and learning outcomes of students. In addition, through this activity is targeted the compilation of science learning devices by teachers of trainees by applying research-based learning model to integrate character education in Physics learning in SMA / SMK. The chosen method is to carry out training activities of the application of research-based learning model to integrate character education for high school teachers / vocational schools in Gorontalo city. The training activities will begin with the provision of materials on research-based learning models, character education, and dissemination of research learning tools and simulations of the application of instructional learning tools. Furthermore, the following activities are guiding the preparation of learning tools and simulation of the devices that have been prepared. This dedication activity ends with the evaluation in the form of direct practice in each school which will be observed directly by the implementing team of IbM and the school 
supervisor. The results achieved in the implementation of this IbM activity is the Physics Teachers of SMA / SMK can design and develop learning tools through the application of research-based learning model to integrate character education and can apply it in the learning process, resulting 20 pieces Learning tools (including RPP, Teaching Materials, LKPD, Test of Learning Outcomes, student-based activity instruments and Student character appraisal instruments) compiled by participants of training activities.

Keywords: Character building, Physics, Research-based learning model, SMA/SMK.

\section{PENDAHULUAN}

Sebagai bangsa, kita mencatat lahirnya berbagai kebijakan pemerintah yang tujuannya adalah untuk perubahan sistem nasional, yang dipercaya dapat meningkatkan kualitas pendidikan secara umum. Secara khusus, perubahan sistem melalui peningkatan kompetensi guru dan sertifikasinya, pengakuan akan status professional guru dan perbaikan penerimaan guru, penggunaan teknologi informasi dan komunikasi dalam kelas, termasuk pembangunan infrastruktur yang diperlukan, dipercaya akan memajukan proses pembelajaran.

Menurut Willi (2012) walaupun banyak hal yang telah dilakukan, saat ini sebagai bangsa kita diberi-tahu bahwa gagasan, dan upaya melaksanakan misi mencerdaskan kehidupan bangsa secara utuh masih tertinggal - "the mission has not been fully accomplished". Keprihatinan mendalam yang disebut sebelumnya memang beralasan kuat. Beberapa diantaranya amat kritikal dan mempengaruhi secara negatif" dayasaing-bangsa"

Fakta menunjukkan bahwa 90\% dari lulusan Ujian Nasional SMA/SMK tahun 2015, hanya mencapai nilai rata-rata 64.4 (Kemendikbud, 2015). Angka ini termasuk lulusan dari berbagai kabupaten di daerah yang sekolahnya mencapai angka kelulusan 100\%, walaupun diketahui bahwa sekolahsekolah tersebut memiliki fasilitas yang sangat minimal dan tidak memiliki guru dalam jumlah dan kualitas yang cukup, dengan etos kerja yang memprihatinkan. Apabila kecenderungan ini meluas, maka dapat dikatakan bahwa 90\% dari lulusan SMA/SMK di Indonesia di tahun 2014, memiliki resiko yang tinggi (walaupun tidak mutlak) untuk gagal di Perguruan Tinggi. Jikalau nilai rata-rata 50 hingga 60 didudukan dalam rentangan kelayakan tingkat kesukaran pembelajaran, nilai ratarata merupakan indikasi bahwa perguruan tinggi mendapatkan pembelajar yang pasif dan amat bergantung pada dosennya sebagai satu-satunya sumber informasi.

Survey awal di Kota Gorontalo menunjukkan pembelajaran yang pasif dalam proses pembelajaran fisika di SMA/SMK, secara umum alat-alat laboratorium di sekolahsekolah sangat jarang digunakan, padahal jika digunakan dengan tepat melalui pembelajaran berbasis riset tentulah akan lebih bermakna bagi peserta didik. Siswa sekarang membutuhkan pengetahuan dan keterampilan yang relevan, termasuk 
berkomunikasi secara efektif untuk berfungsi sebagai warga negara yang produktif. Oleh karena itu kurikulum sekolah perlu mengembangkan kemampuan siswa untuk, "imagine the possible future"; "forcasting probable future" dan yang yang terpenting "deciding on preferable future". Tentu bukan membuat keputusan tentang masa depan dengan imajinasi berbasis mimpi belaka, tetapi suatu kemampuan membangun skenario yang berbasis pengetahuan yang memiliki "evidence" dari proses studi yang berbasis-riset. Pembelajaran berbasis riset memiliki tujuh karakteristik yang terlihat dalam proses pembelajarannya. Karakteristik tersebut menurut Widyawati dan Tri Diah (2010) meliputi: sistematik, aktif, kreatif, inovatif, efektif, objektif, dan ilmiah.

Dalam penerapannya model pembelajaran berbasis riset dapat diintegrasikan dengan pendidikan karakter, sehingga pembelajaran yang dilaksanakan bukan hanya menghasilkan ilmuwan yang cerdas akan tetapi menghasilkan ilmuwan yang cerdas dan berkarakter. Pendidikan karakter dimaknai sebagai pendidikan nilai, budi pekerti, moral, yang tujuannya mengembangkan kemampuan siswa untuk mewujudkan karakter positif dalam kehidupan sehari-hari (Puskur, 2010).

Berdasarkan hal tersebut, maka muatan pendidikan karakter difokuskan pada attitudes, behavior, emotions, dan cognitions (Berkowitz,
2005). Lebih lanjut Rosyiidah (2013), menegaskan bahwa pendidikan karakter identik dengan nilai kebajikan yang diketahui, dihayati dan diamalkan. Pendidikan karakter penting untuk dikembangkan dan terus dikawal, karena pendidikan karakter merupakan realisasi nilai, pendidikan watak, pendidikan kewarganegaraan dan pendidikan moral (Zuchdi et al., 2011).

Hasil wawancara dengan beberapa guru SMA/SMK di Kota Gorontalo kurangnya pelatihan tentang pengembangan dan penerapan berbagai model pembelajaran berintegrasi pendidikan karakter pada pembelajaran fisika menjadi alasan minimnya variasi model pembelaran fisika berintegrasi karakter. Hal ini berdampak pada rendahnya hasil belajar siswa pada mata pelajaran IPA, dimana rata-rata nilai Fisika Ujian Sekolah di tingkat SMA/SMK di Kota Gorontalo adalah 45 (Sumber : Data Dinas Pendidikan Nasional Kota Gorontalo)

Survey lanjutan dengan

melakukan wawancara dengan beberapa guru fisika SMA/SMK di Kota Gorontalo, diperoleh informasi bahwa beberapa tahun terakhir ini kelompok guru mata pelajaran Fisika tidak melakukan kegiatan-kegiatan pengembangan keilmuwan dan keterampilan profesionalisme guru karena tidak adanya anggaran untuk kegiatan tersebut. melalui kegiatan pelatihan bagi guru fisika SMA/SMK tentang model pembelajaran berbasis riset berintegrasi pendidikan karakter, diharapkan dapat meningkatkan 
keterampilan dan keilmuwan guru fisika, sehingga pada akhirnya peserta didik lulusan SMA/SMK memiliki keterampilan yang memadai ketika berada di jenjang perguruan tinggi kelak. Ini jelas harus dipersiapkan oleh pelaksana pendidikan sehingga diharapkan peserta didik lulusan SMA/SMK tidak menjadi mahasiswa pasif kelak di perguruan tinggi tapi memiliki keterampilan-keterampilan dan jiwa seorang peneliti.

\section{METODE PENELITIAN}

1. Metode Pendekatan

Untuk mengatasi masalah yang dihadapi oleh mitra ini akan dilaksanakan suatu kegiatan pelatihan penerapan model pembelajaran berbasis riset berintegrasi pendidikan karakter bagi guru Fisika SMA/SMK se Kota Gorontalo. Berikut ini diuraikan metode pendekatan yang akan digunakan untuk menyelesaikan masalah-masalah yang dihadapi oleh mitra IbM.

a. Rendahnya aktivitas belajar peserta didik di SMA/SMK

Langkah yang diambil adalah meningkatkan keilmuwan dan keterampilan guru tentang model pembelajaran riset yang diharapkan melalui penerapan model ini dapat meningkatkan aktivitas siswa dalam proses pembelajaran.

b. Rendahnya hasil belajar siswa SMA/SMK pada mata pelajaran Fisika baik pada Ujian Akhir Sekolah maupun Ujian Akhir Nasional
Langkah yang dapat diambil untuk menyelesaikan masalah ini, diantaranya dengan meningkatkan mutu pendidik dalam hal ini keilmuwan dan keterampilan pedagogis guru melalui kegiatan pelatihan ini

c. Sangat minimnya pengetahuan dan keterampilan guru SMA/SMK tentang model pembelajaran berbasis riset

Masalah ini dapat diatasi dengan melakukan pendekatan dalam bentuk penyampaian teori-teori tentang pembelajaran berbasis riset berintegrasi pendidikan karakter, termasuk contoh perangkat pembelajaran yang telah dikembangkan dalam penelitian Hibah Bersaing

d. Belum adanya pelatihanpelatihan yang dapat meningkatkan keilmuwan dan keterampilan guru dalam hal penerapan model pembelajaran riset berintegrasi pendidikan karakter dalam pembelajaran fisika di SMA/SMK

Untuk mengatasi masalah tersebut, maka melalui dana pengabdian DP2M DIKTI akan dilaksanakan kegiatan pelatihan yang bertujuan untuk meningkatkan keilmuwan dan keterampilan guru Fisika SMA/SMK tentang penerapan model pembelajaran berbasis riset berintegrasi pendidikan karakter.

\section{Prosedur Kerja}

Tim IbM Universitas Negeri Gorontalo dengan melibatkan mitra dalam pelaksanaan kegiatan ini akan 
melaksanakan kegiatan pelatihan penerapan model pembelajaran berbasis riset berintegrasi pendidikan karakter. Kegiatan pelatihan ini dilaksanakan selama 3 bulan bagi guru fisika SMA/SMK se Kota Gorontalo, dengan prosedur kerja dalam kegiatan ini meliputi kegiatankegiatan yang diuraikan berikut ini.

1. Kegiatan pelatihan ini diawali dengan pemberian teori (mencakup 30\% dari materi pelatihan) tentang model pembelajaran berbasis riset berintegrasi pendidikan karakter, termasuk perangkat pembelajaran Fisika yang telah dikembangkan melalui penelitian kami yang didanai oleh dana Hibah Bersaing (2014 dan 2015).
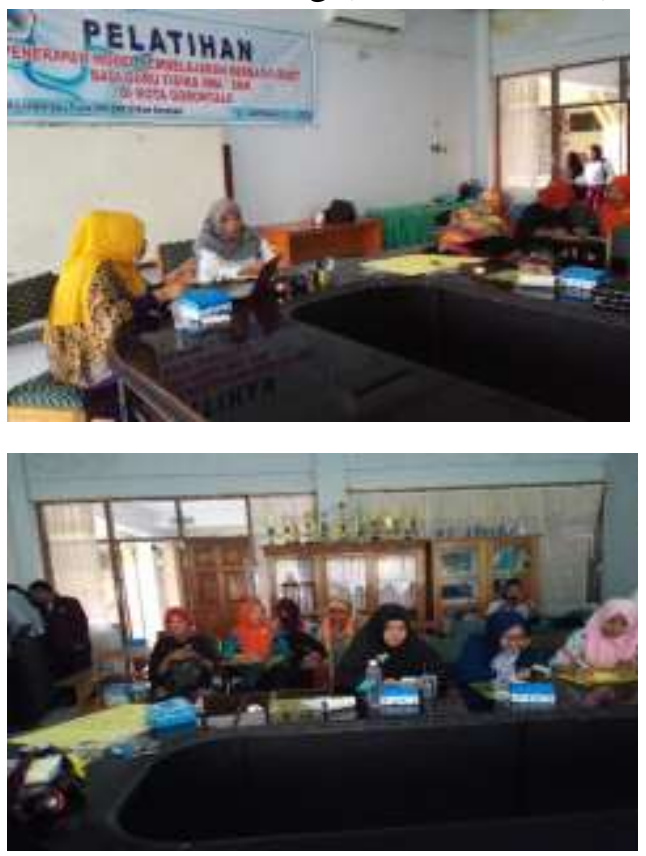

Gambar 1. Peserta menerima materi pelatihan

2. Setelah mendapatkan teori, kegiatan pelatihan dilanjutkan dengan praktek $(70 \%$ dari materi pelatihan). Praktek pada kegiatan pelatihan ini meliputi sebagai berikut.

a. Simulasi penerapan model pembelajaran berbasis riset berintegrasi pendidikan karakter dengan menggunakan perangkat pembelajaran yang dikembangkan/dihasilkan pada penelitian hibah bersaing

b. Kegiatan praktek dilanjutkan dengan penyusunan perangkat pembelajaran oleh peserta pelatihan (terdiri atas RPP, Buku Ajar, LKPD Tes Hasil Belajar, intrumen aktivitas berbasis riset dan instrumen penilaian karakter peserta didik) untuk satu kompetensi dasar yang diajarkan di sekolah. Kegiatan ini dibimbing langsung tim pelaksana IbM

c. Kegiatan dilanjutkan dengan pendampingan simulasi, dimana pada kegiatan ini beberapa orang guru mensimulasikan perangkat pembelajaran yang telah disusun selama kegiatan pelatihan.

d. Pada akhir kegiatan dilaksanakan pendampingan ujian, seluruh peserta akan menggunakan perangkat pembelajaran yang telah disusun dalam proses pembelajaran di sekolah masing-masing, dengan diamati oleh pelaksana IbM dan pengawas. 

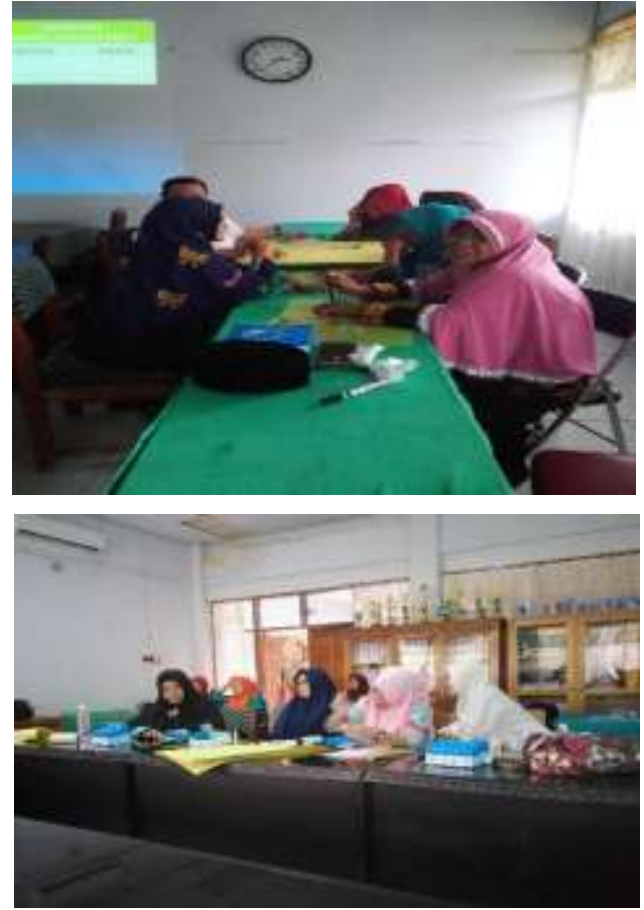

Gambar 2. Peserta menyusun rencana pembelajaran dan mensimulasikan model pembelajaran berbasis riset berintegrasi pendidikan karakter

\section{HASIL DAN PEMBAHASAN}

Target dalam pelaksanaan kegiatan pelatihan ini adalah peningkatan keilmuwan dan keterampilan guru fisika SMA/SMK di Kota Gorontalo tentang penerapan model pembelajaran berbasis riset yang berintegrasi pendidikan karakter.

Kegiatan pelatihan ini diawali dengan pemberian teori (mencakup $30 \%$ dari materi pelatihan). Teori yang diberikan adalah teori tentang model pembelajaran berbasis riset. Pengetahuan tentang model pembelajaran riset penting untuk dimiliki oleh guru fisika SMA/SMK mengingat bahwa Pembelajaran berbasis riset (PBR) merupakan salah satu metode student centered learning (SCL) yang mengintegrasikan riset di dalam proses pembelajaran.

Menurut Slameto (2015) PBR bersifat multifaset yang mengacu kepada berbagai macam metode pembelajaran. PBR memberi kesempatan kepada siswa untuk mencari informasi, menyusun hipotesis, mengumpulkan data, menganalisis data, dan membuat kesimpulan atas data yang sudah tersusun. Keterampilan ini relevan dengan pembelajaran fisika di SMA/SMK, sehingga wajib dikuasai oleh siswa.

Berdasarkan hal tersebut, maka guru bukan hanya dibekali dengan pengetahuan akan teori model PBR, akan tetapi juga dibekali dengan pengetahuan tentang penerapan model PBR dalam pembelajaran fisika.

Selain membekali guru dengan model PBR, pelatihan ini juga membekali guru dengan pengetahuan bagaimana mengintegrasikan pendidikan karakter dalam pembelajaran berbasis riset. Hal ini penting karena pendidikan karakter sangat penting dalam pencapaian kebahagiaan individu, keluarga, dan masyarakat/Negara (Ngamanken, 2014).

Setelah memberikan teori model pembelajaran riset berintegrasi pendidikan karakter, maka kegiatan pelatihan dilanjutkan dengan praktek (70\% dari materi pelatihan). Praktek pada kegiatan pelatihan ini meliputi: 1) kegiatan simulasi penerapan model pembelajaran berbasis riset 
berintegrasi pendidikan karakter menggunakan perangkat pembelajaran hasil penelitian; 2) kegiatan praktek penyusunan perangkat pembelajaran berbasis riset berintegrasi pendidikan karakter; 3) simulasi menggunakan perangkat pembelajaran yang telah disusun oleh peserta dan 4) ujian praktek mengajar dengan menggunakan model pembelajaran berbasis riset berintegrasi pendidikan karakter.

Kegiatan praktek dimulai dengan kegiatan simulasi model Pembelajaran Berbasis Riset (PBR) dengan menggunakan perangkat pembelajaran yang dihasilkan pada penelitian sebelumnya, dimana kegiatan pelatihan ini merupakan implmentasi dari hasil penelitian yang telah dilakukan oleh tim pelaksana IbM. Kegiatan simulasi ini dilakukan dengan melaksanakan proses pembelajaran, dimana tim IbM bertindak sebagai guru, sedangkan peserta bertindak sebagai siswa. Kegiatan ini mendapat respon positif dari guru yang mengikuti kegiatan ini.

Respon positif guru pada kegiatan ini juga ditunjukkan dengan keaktifan guru dalam menyusun perangkat Pembelajaran Berbasis Riset (PBR) berintegrasi pendidikan karakter. Seluruh peserta aktif menyusun perangkat pembelajaran.

Dikutip dari Kemenristekditi Direktorat Jenderal Pembelajaran dan Kemahasiswaan (2017) perangkat pembelajaran terdiri dari perencanaan proses pembelajaran, buku ajar /modul ajar/diktat, sedangkan menurut Ismaniati (2017) perangkat pembelajaran terdiri atas Silabus/Rencana Pembelajaran Semester (RPS), Satuan Acara Pembelajaran (SAP) atau Rencana Pelaksanaan Pembelajaran (RPP), lembar kegiatan mahasiswa (LKM), modul ajar (materi), instrument penilaian hasil belajar, media pembelajaran, kalender pendidikan, hasil analisis pembelajaran dan lainlain.

Dalam kegiatan ini perangkat pembelajaran yang disusun oleh guru adalah Rencana Pelaksanaan Pembelajaran (RPP), Lembar Kegiatan Peserta Didik (LKPD), Modul Ajar, dan Tes Hasil Belajar. Peserta terlihat antusias selama penyusunan perangkat pembelajaran, hal-hal yang tidak mengerti oleh guru langsung ditanyakan kepada tim IbM dan langsung dibimbing oleh tim IbM, sehingga diakhir kegiatan pelatihan $95 \%$ guru dapat menyusun perangkat pembelajaran dengan kualitas baik. Melalui bimbingan intensif, guru yang memiliki kesulitan dalam penyusunan perangkat ini dapat menyelesaikan tugas yang diberikan. Kegiatan ini menghasilkan 20 perangkat pembelajaran berbasis riset berintegrasi pendidikan karakter.

Kegiatan selanjutnya adalah mensimulasikan perangkat pembelajaran yang telah disusun oleh guru selama kegiatan pelatihan. Simulasi ini dilakukan oleh beberapa peserta yang terpilih bertindak sebagai guru, sedangkan peserta lainnya bertindak sebagai siswa. 
Pada saat kegiatan simulasi, semua peserta berperan aktif dalam proses pembelajaran. Mereka sangat tertarik dengan model pembelajaran yang dipraktekkan dan setiap aktivitas yang dituntut untuk dilaksanakan selama proses pembelajaran dilaksanakan dengan penuh semangat, setiap tugas pembelajaran dilaksanakan tepat waktu.

Kegiatan pelatihan diakhiri dengan ujian praktek yang diikuti oleh seluruh peserta kegiatan. Ujian praktek dilaksanakan di sekolah asal peserta. Pada kegiatan ini, guru menyusun perangkat pembelajaran berbasis riset berintegrasi pendidikan karakter kemudian mempraktekkannya dalam proses pembelajaran di kelas. Hasil penilaian menunjukkan $100 \%$ peserta pelatihan dapat menyusun perangkat pembelajaran berbasis riset dan dapat menerapkannya dalam proses pembelajaran. Hal ini menunjukkan bahwa kegiatan pelatihan ini efektif meningkatkan keilmuwan dan keterampilan guru fisika SMA/SMK dalam mengimplementasikan model pembelajaran berbasis riset berintegrasi pendidikan karakter.

\section{SIMPULAN}

Hasil yang dicapai pada pelaksanaan kegiatan IbM ini adalah sebagai berikut.

1. Peserta dapat menyusun perangkat pembelajaran menggunakan model pembelajaran berbasis riset berintegrasi pendidikan karakter dengan baik dan dapat menerapkannya dengan baik dalam proses pembelajaran.

2. Dihasilkan 20 buah Perangkat pembelajaran (meliputi RPP, Buku Ajar, LKS dan Tes Hasil Belajar) yang disusun oleh peserta kegiatan pelatihan.

3. Peserta dapat mengimplementasikan model pembelajaran berbasis riset berintegrasi pendidikan karakter dalam proses pembelajaran di kelas.

\section{DAFTAR PUSTAKA}

Berkowitz, Marvin W dan Melinda C Bier (2005). What Works in Character Education: A Research-Driven Guide for Educators. Washinton: Character Education Partnership.

Ismaniati, Christina. 2018. Penyusunan Perangkat Pembelajaran. https://docplayer.info/6194676 5-Penyusunan-perangkatpembelajaran-oleh-dr-christinaismaniati-m-pd.html. Diakses 20 Januari 2018

Kementerian Pendidikan dan Kebudayaan. 2015. Laporan Hasil Ujian Nasional. Pusat penilaian Pendidikan.

Kementerian Riset teknologi dan perguruan tinggi direktorat jenderal pembelajaran dan kemahasiswaan. 2017. Panduan penyusunan perangkat pembelajaran dan bahan ajar.

Ngamanken, Stephanus. 2014. Pentingnya Pendidikan 
Nova Elysia Ntobuo', Asri Arbie', Lanto M. Kamil Amali³/Aksiologiya: Jurnal Pengabdian Kepada Masyarakat. Vol.3, No.2, Agustus 2019 Hal 124 - 132

Karakter. Jurnal Humaniora, 5 (1): 72-87.

Puskur (2010a). Grand Design

Pendidikan Karakter. Jakarta:

Kemdiknas

Rosyiidah, Afiifah Al. 2013.

"Pendidikan Karakter pada

Classic Fairy Tales". Jurnal

Pedidikan Karakter, Tahun III/

Nomor 3. h. 252. Yoyakarta:

LPPMP UNY.

Slameto. 2015. Pembelajaran

Berbasis Riset Mewujudkan

Pembelajaran yang Inspiratif.

Satya Widya 31 (2): 102-113.
Widyawati dan Tri Diah. 2010.

Pedoman umum pembelajaran

Berbasis Riset (PUPBR).

Kerjasama antara Pusat

Pengembangan Pendidikan,

Kantor Jaminan Mutu, dan

Lembaga Penelitian dan

Pengabdian Kepada MAsyarakat

UGM. Universitas Gajah Mada

Willi Toisuta. 2012. Pembelajaran Berbasis Penelitian.

https://wta.co.id/pembelajaranberbasis-penelitian . Diakses 23 Januari 2017.

Zuchdi, Darmiyati, et. al. 2012. Pendidikan Karakter

Terintegrasi, Konsep Dasar dan Implementasi di Perguruan Tinggi. Yogyakarta: UNY Press. 